\title{
Salt sensitivity of the vegetative and reproductive stages in chickpea (Cicer arietinum L.): Podding is a particularly sensitive stage
}

\author{
Srinivasan Samineni ${ }^{\text {a,d }}$, Kadambot H.M. Siddique ${ }^{\text {b,c }}$, Pooran M. Gaur ${ }^{\text {d }}$, Timothy David Colmer ${ }^{\text {a,b,c,* }}$ \\ a School of Plant Biology (M084), The University of Western Australia, 35 Stirling Highway, Crawley, WA 6009, Australia \\ ${ }^{\mathrm{b}}$ The UWA Institute of Agriculture, The University of Western Australia, 35 Stirling Highway, Crawley, WA 6009, Australia \\ ${ }^{c}$ Centre for Legumes in Mediterranean Agriculture, The University of Western Australia, 35 Stirling Highway, Crawley, WA 6009, Australia \\ d International Crops Research Institute for the Semi-Arid Tropics (ICRISAT), Patancheru 502 324, AP, India
}

\section{A R T I C L E I N F O}

\section{Article history:}

Received 14 August 2010

Received in revised form 9 December 2010

Accepted 19 December 2010

\section{Keywords:}

Abiotic stress

Tissue sodium

Tissue chloride

Salinity tolerance

Pollen viability

Chickpea (Cicer arietinum L.)

\begin{abstract}
A B S T R A C T
Soil salinity is an increasing problem, including in regions of the world where chickpea is cultivated. Salt sensitivity of chickpea was evaluated at both the vegetative and reproductive phase. Root-zone salinity treatments of $0,20,40$ and $60 \mathrm{mM} \mathrm{NaCl}$ in aerated nutrient solution were applied to seedlings or to older plants at the time of flower bud initiation. Even the reputedly tolerant cultivar JG11 was sensitive to salinity. Plants exposed to $60 \mathrm{mM} \mathrm{NaCl}$ since seedlings, died by $52 \mathrm{~d}$ without producing any pods; at $40 \mathrm{mM} \mathrm{NaCl}$ plants died by $75 \mathrm{~d}$ with few pods formed; and at $20 \mathrm{mM} \mathrm{NaCl}$ plants had $78-82 \%$ dry mass of controls, with slightly higher flower numbers but 33\% less pods. Shoot $\mathrm{Cl}$ exceeded shoot Na by $2-5$ times in both the vegetative and reproductive phase, and these ions also entered the flowers. Conversion of flowers into pods was sensitive to $\mathrm{NaCl}$. Pollen from salinized plants was viable, but addition of $40 \mathrm{mM}$ $\mathrm{NaCl}$ to an in vitro medium severely reduced pollen germination and tube growth. Plants recovered when $\mathrm{NaCl}$ was removed at flower bud initiation, adding new vegetative growth and forming flowers, pods and seeds. Our results demonstrate that chickpea is sensitive to salinity at both the vegetative and reproductive phase, with pod formation being particularly sensitive. Thus, future evaluations of salt tolerance in chickpea need to be conducted at both the vegetative and reproductive stages.
\end{abstract}

(c) 2011 Elsevier B.V. All rights reserved.

\section{Introduction}

Worldwide, about $20 \%$ of cultivated land is affected by salinity (Ghassemi et al., 1995). Cool season food legumes such as chickpea, lentil and faba bean, are relatively sensitive to salinity (Stoddard et al., 2006). Saline soils occur mainly in arid and semi-arid regions. Chickpea is the major grain legume in these regions (Ali et al., 2002) so saline soils constrain chickpea production in many parts of the world (Ryan, 1997). In chickpea, salinity leads to leaf necrosis and reduced vegetative growth (Maliro et al., 2008) and impedes flower and pod formation (Manchanda and Sharma, 1989; Katerji et al., 2001; Vadez et al., 2007). Salinity of only $3 \mathrm{dS} \mathrm{m}^{-1}$ in field soils was the threshold for reduced shoot growth and yield in chickpea (Rao et al., 2002; Katerji et al., 2005), although this exceeds the even lower salinity threshold $\left(<1.3 \mathrm{dS} \mathrm{m}^{-1}\right)$ in some tropical

\footnotetext{
* Corresponding author at: School of Plant Biology (M084), The University of Western Australia, 35 Stirling Highway, Crawley, WA 6009, Australia. Tel.: +61 86488 1993; fax: +61 864881108

E-mail addresses: samins02@student.uwa.edu.au (S. Samineni), kadambot.siddique@uwa.edu.au (K.H.M. Siddique), p.gaur@cgiar.org (P.M. Gaur), timothy.colmer@uwa.edu.au (T.D.Colmer).
}

legumes like cowpea, soybean and pigeon pea (Keating and Fisher, 1985).

Plant responses to salinity differ depending upon growth/developmental stage, and length of exposure (Munns and Tester, 2008). Salinity tolerance in chickpea has been evaluated at different growth stages, but each individually and with a focus to identify tolerant genotypes (Flowers et al., 2010). For example, salinity tolerance has been evaluated at germination (Garg and Gupta, 1998; Khalid et al., 2001; Singh, 2004), seedling growth up to 3 weeks (Al-Mutata, 2003; Karajeh et al., 2003), vegetative stage up to 8 weeks (Elsheikh and Wood, 1990), and some studies have extended into the reproductive stage (Sadiki and Rabih, 2001; van Hoorn et al., 2001; Bruggeman et al., 2003; Katerji et al., 2005; Vadez et al., 2007). Germination is less sensitive to salinity than early vegetative growth (Garg and Gupta, 1998; Zurayk et al., 1998; Sekeroglu et al., 1999; Al-Mutata, 2003) and the reproductive phase is considered to be even more sensitive than vegetative growth (Vadez et al., 2007). In contrast with chickpea, cowpea is most salt sensitive during the vegetative stage (Maas and Poss, 1989). Thus, the present experiments directly assessed salt sensitivity of chickpea at the reproductive phase, using $\mathrm{NaCl}$ dose-response experiments with treatments applied not only during the vegetative phase but also at flower initiation, 
to enable evaluation of the sensitivity of the reproductive phase without carry-over effects of prior exposure during the vegetative phase. Furthermore, ion $(\mathrm{Na}, \mathrm{K}$ and $\mathrm{Cl}$ ) regulation in roots, shoots, and floral organs, as well as pollen viability and sensitivity to $\mathrm{NaCl}$, were all evaluated as potential contributors to salt sensitivity in chickpea.

Tissue ion regulation is a key trait for salt tolerance in plants (Munns and Tester, 2008), but whether $\mathrm{Na}$ or Cl 'exclusion' contributes to tolerance in chickpea remains uncertain. Two reputedly tolerant genotypes displayed contrasting responses: CM 663 accumulated higher levels of $\mathrm{Na}\left(95 \mu \mathrm{mol} \mathrm{g}^{-1}\right.$ fresh mass) in leaves compared with roots ( $20 \mu \mathrm{mol} \mathrm{g}^{-1}$ fresh mass) whereas ICC 10572 accumulated higher Na in roots $\left(60 \mu \mathrm{mol} \mathrm{g}^{-1}\right.$ fresh mass) than in leaves ( $35 \mu \mathrm{mol} \mathrm{g}^{-1}$ fresh mass), although the $\mathrm{Cl}$ concentration was always more in leaves than in roots for both genotypes (Ashraf and Waheed, 1993). These authors could not separate the toxic effect of $\mathrm{Na}$ and/or $\mathrm{Cl}$ and concluded that leaf $\mathrm{Na}$ and/or $\mathrm{Cl}$ concentrations cannot simply be used as selection criteria for identification of salt tolerance in chickpea. Other studies have found tolerant chickpea genotypes display preferential accumulation of $\mathrm{Na}$ in roots rather than in shoots (Sleimi et al., 2001; Baalbaki et al., 2000). Similarly, lower shoot ion concentrations were observed in a tolerant genotype (i.e., half the $\mathrm{Na}$ and $\mathrm{Cl}$ in a sensitive genotype), but only when ion concentrations were expressed on a tissue water content basis; these differences were not evident on a dry mass basis (Dua, 1998). Dua and Sharma (1997) also reported that growth reductions were associated with higher concentrations of $\mathrm{Na}$ and $\mathrm{Cl}$ in chickpea. However, in a salinity screening experiment no relation was found between final yield and $\mathrm{Na}$ (\% dry mass) in shoots at the vegetative stage (Vadez et al., 2007). It therefore appears that in chickpea a combination of mechanisms (e.g. ion exclusion and tissue tolerance of excess ions) are likely to contribute to salt tolerance.

Understanding salt tolerance and its component traits related to ontogenic stages would facilitate development of salt tolerant genotypes. The present study evaluated the effect of $\mathrm{NaCl}$ (three concentrations) applied at two stages (seedling or early reproductive stages) on growth, tissue ion concentrations, and flowering/podding in chickpea. A similar approach of first adding salinity to chickpea at the early flowering stage in sand culture was used by Dhingra and Varghese (1993) to study flower numbers and pollen production, but growth, tissue ion concentrations, and pod production were not reported. The present study imposed three $\mathrm{NaCl}$ treatments either on seedlings or on plants at the start of the reproductive phase (flower bud initiation). Salinity treatments continued for both these sets of plants, and in addition, to assess recovery, a third set of plants that had been exposed to $\mathrm{NaCl}$ since seedlings were transferred to $\mathrm{NaCl}$-free conditions at the start of the reproductive phase. This experimental approach enabled the hypothesis to be tested that the reproductive phase is the most salt sensitive stage in chickpea, without carry-over effects of prior salt exposure during the vegetative phase.

\section{Materials and methods}

The chickpea desi cultivar 'JG 11', widely grown in southern India, has been identified by Vadez et al. (2007) as relatively salt tolerant (ranked 13th in salt screening of the ICRISAT mini-core plus reference collection). It is a medium-maturity cultivar; flowering commences 37-40 d after sowing; and it matures within $90 \mathrm{~d}$ at ICRISAT, Patancheru, India.

\subsection{Plant growth}

The experiment was conducted at The University of Western Australia, Perth, with a completely randomized design in a phy- totron (natural light) with $20 / 15^{\circ} \mathrm{C}$ day/night temperatures during winter and spring 2007. Plants were grown in continuously aerated nutrient solution within $4.5 \mathrm{~L}$ plastic pots covered with Al-foil to prevent entry of light.

The nutrient solution contained (in $\mathrm{mM}$ ): $5.0 \mathrm{Ca}^{2+}, 3.75 \mathrm{~K}^{+}, 3.125$ $\mathrm{NH}_{4}^{+}, 0.4 \mathrm{Mg}^{2+}, 0.2 \mathrm{Na}^{+}, 5.4 \mathrm{SO}_{4}{ }^{2-}, 6.875 \mathrm{NO}_{3}{ }^{-}, 0.2 \mathrm{H}_{2} \mathrm{PO}_{4}{ }^{-}, 0.1$ $\mathrm{SiO}_{3}{ }^{2-}, 0.1 \mathrm{Fe}$-sequestrene, $0.05 \mathrm{Cl}^{-}, 0.025 \mathrm{BO}_{3}{ }^{3-}, 0.002 \mathrm{Mn}^{2+}$, $0.002 \mathrm{Zn}^{2+}, 0.0005 \mathrm{Cu}^{2+}, 0.0005 \mathrm{MoO}_{4}{ }^{2-}, 0.001 \mathrm{Ni}^{2+}$ and 1.0 MES buffer. $\mathrm{KOH}$ was used to adjust the $\mathrm{pH}$ to 6.5 every second $\mathrm{d}$. The nutrient solution was renewed at 10 -d intervals, at which time pots were re-randomized to minimize the potential influence of environmental heterogeneity in the phytotron.

Seeds were surface sterilized with $0.04 \%$ bleach for $300 \mathrm{~s}$, rinsed with tap water and germinated in darkness on plastic mesh floating on aerated 0.1 -strength nutrient solution. After $48 \mathrm{~h}$, germinating seeds were transferred to 0.25 -strength aerated nutrient solution and grown until emergence of the first leaf. Nine-d-old seedlings were transferred to full strength aerated nutrient solution and allowed to grow for another $4 \mathrm{~d}$, at which time treatments were imposed (i.e., $13 \mathrm{~d}$ after imbibition).

\section{2. $\mathrm{NaCl}$ treatments}

Three concentrations of $\mathrm{NaCl}(20,40$ and $60 \mathrm{mM})$ were applied at two stages of plant growth, along with controls without $\mathrm{NaCl}$ (but with $0.2 \mathrm{mM} \mathrm{Na}^{+}$from $\mathrm{Na}_{2} \mathrm{SiO}_{3}$ and $0.05 \mathrm{mM} \mathrm{Cl}^{-}$in the micronutrient stock). Each treatment was replicated seven times, with six plants in each pot to enable six samplings (an initial sample was also taken from extra pots, giving seven sampling times).

Treatments were categorized into three sets based on the time of $\mathrm{NaCl}$ application at different growth stages. Set I was with continuous $\mathrm{NaCl}$ treatments $(0,20,40$ and $60 \mathrm{mM})$, applied $13 \mathrm{~d}$ after imbibition. Set II was without $\mathrm{NaCl}$ until flower bud initiation, treatments were then imposed $(0 \rightarrow 20 \mathrm{mM}, 0 \rightarrow 40 \mathrm{mM}$, and $0 \rightarrow 60 \mathrm{mM}$ ). In all cases, $\mathrm{NaCl}$ was added in steps of $20 \mathrm{mM} \mathrm{NaCl}$ per d. Set III was with $\mathrm{NaCl}$ from $13 \mathrm{~d}$ after imbibition until flower bud initiation and then $\mathrm{NaCl}$ was removed $(20 \mathrm{mM} \rightarrow 0,40 \mathrm{mM} \rightarrow 0$, and $60 \mathrm{mM} \rightarrow 0$ ). This second phase of the experiment, with $\mathrm{NaCl}$ either added for the first time or removed, occurred at flowering ( $50 \%$ of plants showed flower bud initiation; $48 \mathrm{~d}$ after imbibition). The experiment was continued until $111 \mathrm{~d}$ after imbibition.

\subsection{Plant samplings}

Initial samples were taken at the time treatments were imposed, $13 \mathrm{~d}$ after imbibition. The remaining samplings were at 23, 33, $47 \mathrm{~d}$ after imbibition (these three samplings were during the vegetative phase), 65,87 , and $111 \mathrm{~d}$ after imbibition (these three samplings were during the reproductive phase).

At each sampling, plants were separated into roots and shoots. To remove the external treatment solutions, roots were washed three times in $5 \mathrm{mM} \mathrm{CaSO}_{4}$, for $20 \mathrm{~s}$ each time. Surface water was blotted off using paper towels and fresh mass measured. Tissues were oven dried at $65^{\circ} \mathrm{C}$ for $48 \mathrm{~h}$ and dry mass was determined.

Numbers of flower buds, flowers and developing pods were recorded over the final $50 \mathrm{~d}$, at $10 \mathrm{~d}$ intervals. At the final sampling, these reproductive structures were also separated and ovendried.

\subsection{Ion analyses}

$\mathrm{Na}, \mathrm{K}$ and $\mathrm{Cl}$ in tissues were extracted in $0.5 \mathrm{M} \mathrm{HNO}_{3}$ by shaking for $2 \mathrm{~d}$. Na and $\mathrm{K}$ in extracts were analyzed using a flame-photometer (Model PFP7, Jenway, Essex, UK) and $\mathrm{Cl}$ using a Buchler-Cotlove chloridometer (Model 4-2000, Buchler Instruments, Fortlee, USA). A certified reference plant tissue taken 


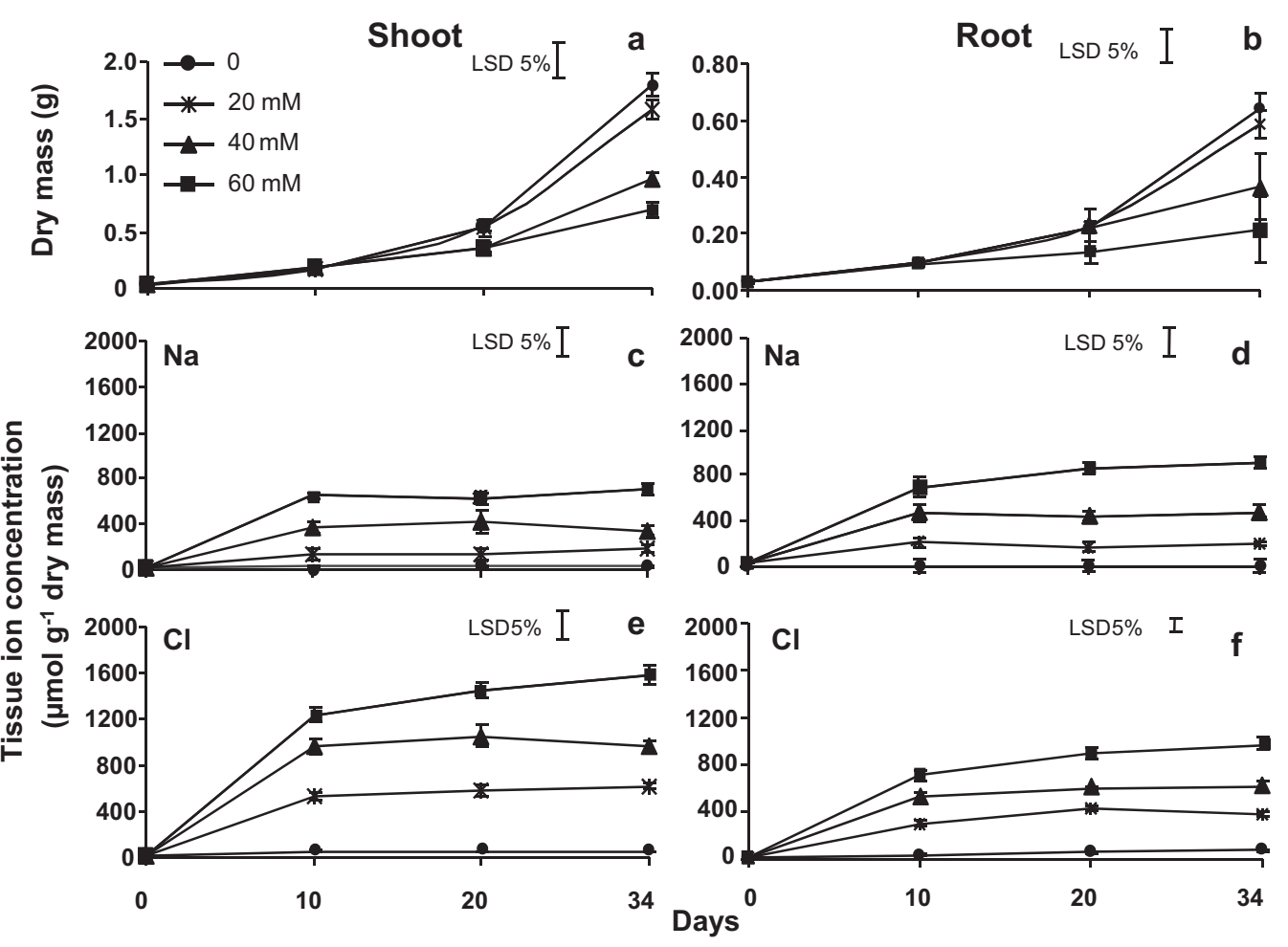

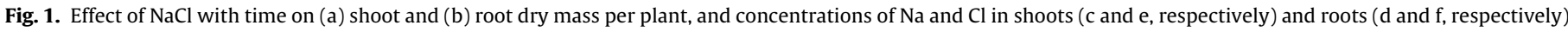

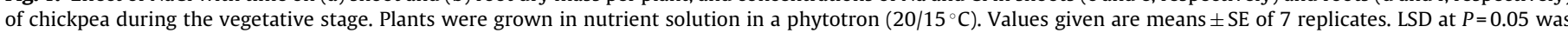
calculated for the data at $34 \mathrm{~d}$ of treatments (i.e., $47 \mathrm{~d}$ after imbibition).

through the same procedures recovered 99\% K, 104\% Na and $92 \%$ $\mathrm{Cl}$. No adjustments were made to the data presented.

\subsection{Pollen viability test}

Pollen was collected from flowers of plants after 35-40 d in the continuous $\mathrm{NaCl}$ treatments (Set I). Two flowers on each plant of seven replicates were used. Pollen germination was tested on cellophane placed on growth media containing $\mathrm{CaCl}_{2} \cdot 2 \mathrm{H}_{2} \mathrm{O}$ (300 $\left.\mathrm{mg} \mathrm{L}^{-1}\right), \mathrm{H}_{3} \mathrm{BO}_{3}\left(100 \mathrm{mg} \mathrm{L}^{-1}\right.$ ) and sucrose $15 \%$ (Brewbaker and Kwack, 1963; Alexander and Ganeshan, 1989) and incubated for $8 \mathrm{~h}$ in darkness at $20-25^{\circ} \mathrm{C}$. Cellophane was lifted and aniline blue fluorescence stain was added before observing under a fluorescence microscope (Carl Zeiss, Germany). Pollen was considered to have germinated when tube length was more than the diameter of the pollen grain. To estimate pollen viability, observations were taken on ten random locations on each slide (approx. 350-1600 pollen grains).

\subsection{Statistical analyses}

Data were analyzed using GENSTAT (Version 10.2) software. Statistical significances for dry mass and ion concentrations in different tissues were evaluated using one-way ANOVA with Duncan's multiple comparison test at $5 \%$ level of significance. Skewed data sets were $\log _{\mathrm{e}}$ transformed prior to ANOVA.

\section{Results}

\subsection{Vegetative phase}

\subsubsection{Symptoms of leaf damage}

Plants exposed to $\mathrm{NaCl}$ treatments developed symptoms of salt damage to leaves, characterized initially by yellowing and subsequent necrosis of margins of older leaves; with time these leaves suffered complete necrosis. These symptoms appeared first in the oldest leaves and then progressively in successively younger leaves (i.e., from base upwards). Initial symptoms appeared in the $60 \mathrm{mM}$ treatment after about $10 \mathrm{~d}$, then $2 \mathrm{~d}$ later in the $40 \mathrm{mM}$ treatment, and another $2 \mathrm{~d}$ later in the $20 \mathrm{mM}$ treatment. The rate of symptom spread was fastest in the $60 \mathrm{mM}$ treatment and slowest in the $20 \mathrm{mM}$ treatment.

\subsubsection{Growth}

Shoot dry mass did not differ among the four $\mathrm{NaCl}$ treatments up to $10 \mathrm{~d}$ after salinization, but by $20 \mathrm{~d}$ plant dry mass in 40 and $60 \mathrm{mM}$ treatments was less than the control and $20 \mathrm{mM}$ treatment (Fig. 1a). After $34 \mathrm{~d}$ of $\mathrm{NaCl}$ treatments, just prior to the commencement of flower bud initiation, shoot dry mass (\% of controls) was $88 \%$ in $20 \mathrm{mM} \mathrm{NaCl}, 54 \%$ in $40 \mathrm{mM} \mathrm{NaCl}$ and $39 \%$ in $60 \mathrm{mM} \mathrm{NaCl}$.

Root dry mass also did not differ across the four $\mathrm{NaCl}$ treatments up to $10 \mathrm{~d}$ after salinization, but by $20 \mathrm{~d}$ root dry mass in $60 \mathrm{mM}$ $\mathrm{NaCl}$ was less than the other treatments (Fig. 1b). After $34 \mathrm{~d}$ of $\mathrm{NaCl}$ treatments, just prior to the commencement of flower bud initiation, root dry mass (\% of control) was $92 \%$ in $20 \mathrm{mM} \mathrm{NaCl}, 59 \%$ in $40 \mathrm{mM} \mathrm{NaCl}$ and $33 \%$ in $60 \mathrm{mM} \mathrm{NaCl}$.

\subsubsection{Ion concentrations in roots and shoots}

Within $10 \mathrm{~d}$ of salinization, $\mathrm{Na}$ in shoots had increased 7.5-fold in the $20 \mathrm{mM} \mathrm{NaCl}$ treatment, 14 -fold in the $40 \mathrm{mM}$ treatment, and 28 -fold in the $60 \mathrm{mM}$ treatment (Fig. 1c). In roots, Na concentration progressively increased in each higher $\mathrm{NaCl}$ treatment (Fig. 1d). Interestingly, after these large increases in tissue Na concentrations during the first $10 \mathrm{~d}$, levels then remained relatively constant in both roots and shoots in all treatments for the next $24 \mathrm{~d}$ (Fig. 1c and d).

Within $10 \mathrm{~d}$ of salinization, $\mathrm{Cl}$ in shoots had increased 12 -fold in the $20 \mathrm{mM} \mathrm{NaCl}$ treatment, 18 -fold in the $40 \mathrm{mM}$ treatment, and 30 -fold in the $60 \mathrm{mM}$ treatment (Fig. 1e). In roots, $\mathrm{Cl}$ concentration 
Shoot
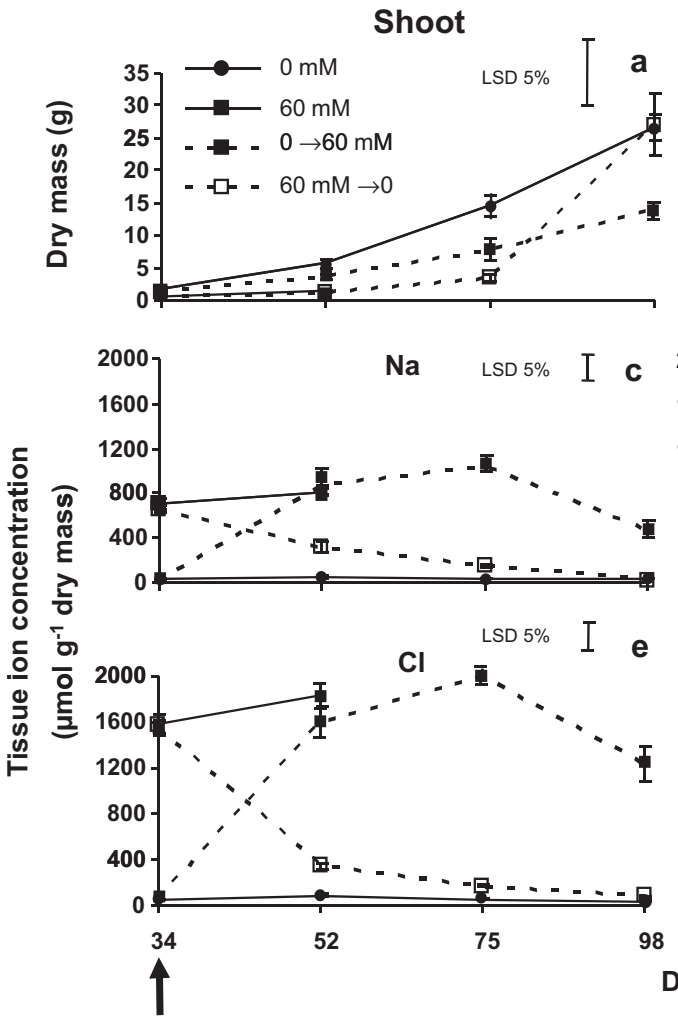

Root
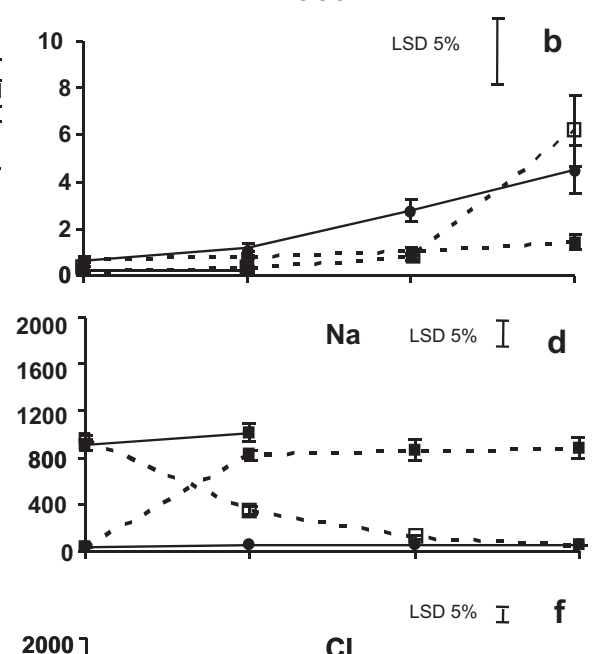

Cl

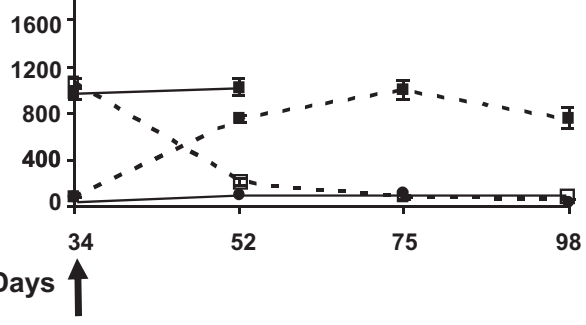

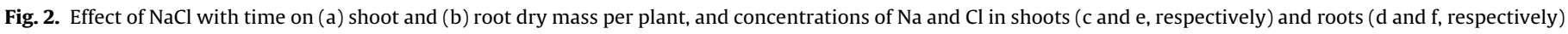

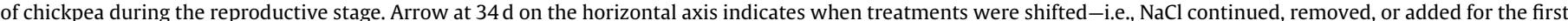

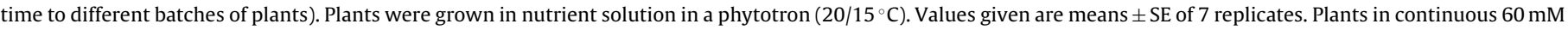
$\mathrm{NaCl}$ concentration died at $52 \mathrm{~d}$ of treatment. LSD at $P=0.05$ was calculated for data at the final sampling (98 d of treatments; i.e., $111 \mathrm{~d}$ after imbibition).

also progressively increased in each higher $\mathrm{NaCl}$ treatment but was much lower than those in shoots (Fig. 1f). After these initial, large increases in tissue $\mathrm{Cl}$ concentrations, levels then remained relatively constant in both roots and shoots of plants in all treatments for the next $24 \mathrm{~d}$ (Fig. 1e and f).

By contrast with the changes in tissue $\mathrm{Na}$ and $\mathrm{Cl}$ described in the preceding paragraphs, shoot $\mathrm{K}$ concentration did not differ significantly between the control and $60 \mathrm{mM} \mathrm{NaCl}$ treatments (data not shown). Root $\mathrm{K}$ concentration, however, had decreased in the $60 \mathrm{mM} \mathrm{NaCl}$ treatment to $74 \%$ of the control, and was $85 \%$ of the control at $40 \mathrm{mM} \mathrm{NaCl}$ (data not shown). The average $\mathrm{K}$ concentrations ( $\mu \mathrm{mol} \mathrm{g}^{-1}$ dry mass) in plants across four treatments were: 920 in shoots and 1670 in roots.

\subsection{Reproductive phase}

For clarity of presentation, and since the responses of plants exposed to 20 or $40 \mathrm{mM} \mathrm{NaCl}$ followed similar patterns, but intermediate to those in controls and $60 \mathrm{mM} \mathrm{NaCl}$, time-series data on growth and tissue ion concentrations are only shown for the controls and $60 \mathrm{mM}$ treatments (Fig. 2). Data for all treatments are given for the final sampling (i.e., $111 \mathrm{~d}$ after imbibition; Figs. 3-5).

\subsubsection{Growth}

Shoot (Fig. 2a) and root (Fig. 2b) dry mass continued to increase in controls during the reproductive phase. Plants continued at $60 \mathrm{mM} \mathrm{NaCl}$ were much smaller than controls (Fig. 2a and b) and although these plants initially increased in dry mass, all leaves suffered complete necrosis (i.e., no green leaves remained) by $52 \mathrm{~d}$ of treatment and no further observations were taken in $60 \mathrm{mM}$ treatment (Fig. 2a and b). Plants that remained in $40 \mathrm{mM} \mathrm{NaCl}$ continued to grow, but by $75 \mathrm{~d}$ of treatment all leaves suffered complete necro-

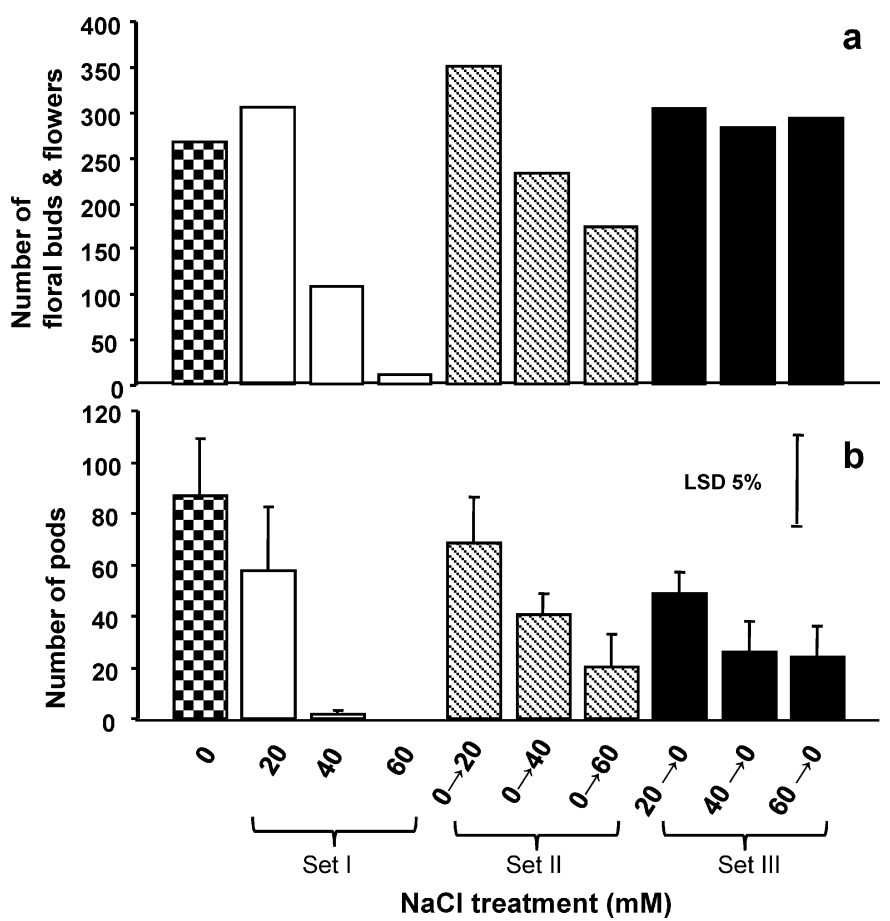

Fig. 3. Total number of buds and flowers per chickpea plant (a) observed over $50 \mathrm{~d}$, at $10 \mathrm{~d}$ intervals, and (b) total numbers of pods per plant at the final sampling ( $98 \mathrm{~d}$ of treatments). Set I-continuous $\mathrm{NaCl}$ treatments; Set II- $\mathrm{NaCl}$ applied at flower bud initiation stage; Set III-NaCl removed at flower bud initiation stage. No pods were formed in continuous $60 \mathrm{mM} \mathrm{NaCl}$ treatment, as plants died. Values given are means \pm SE of 7 replicates. LSD at $P=0.05$ is shown. SE values were not given for flower numbers as these data were cumulative. 


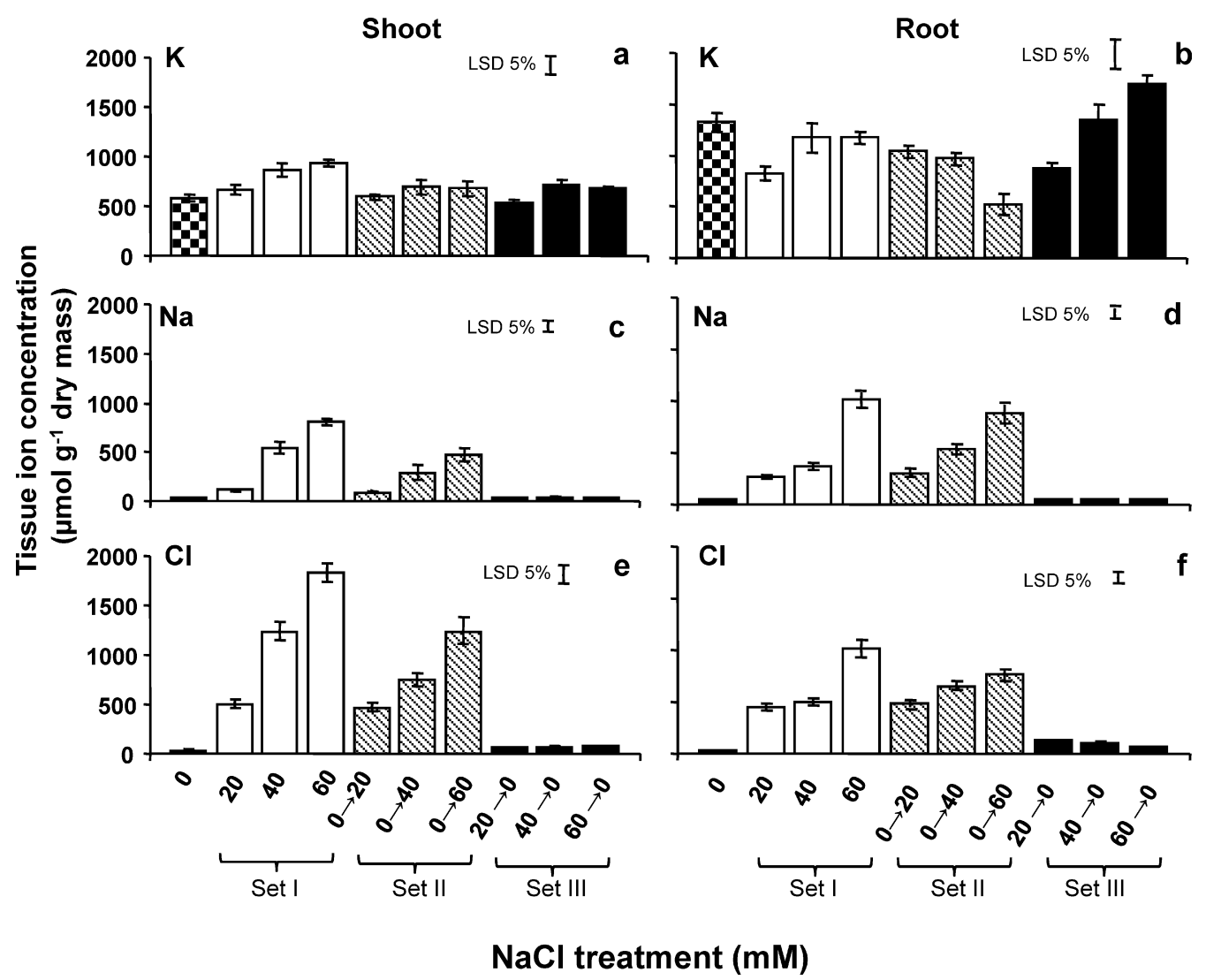

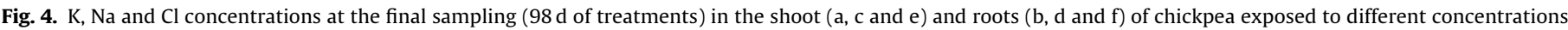

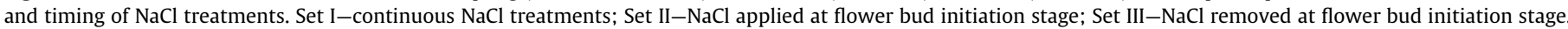
Values given are means \pm SE of 7 replicates. LSD at $P=0.05$ is shown.

sis. Plants in $20 \mathrm{mM} \mathrm{NaCl}$ survived; shoot and root dry mass at the end of the experiment were $78-82 \%$ of controls (Fig. 6). As described below, controls and $20 \mathrm{mM} \mathrm{NaCl}$ treated plants produced numerous pods, but plants treated with $40 \mathrm{mM} \mathrm{NaCl}$ produced few pods prior to death, and with $60 \mathrm{mM} \mathrm{NaCl}$ plants died without producing any pods (Fig. 3).

For plants first exposed to $\mathrm{NaCl}$ treatments at the reproductive stage (Set II), growth was severely stunted at $60 \mathrm{mM}$, such that final dry mass of shoots was $53 \%$ of controls (Fig. 2a) and roots was $32 \%$ (Fig. 2b). At $40 \mathrm{mM} \mathrm{NaCl}$, shoot and root dry mass were $56 \%$ and $34 \%$, respectively, of controls (data not shown). At $20 \mathrm{mM} \mathrm{NaCl}$, shoot and root dry mass were $73 \%$ and $66 \%$, respectively, of controls (data not shown). All plants in treatments first imposed at the reproductive stage produced pods, but numbers declined with increasing $\mathrm{NaCl}$ concentration (see below).

For plants initially in $60 \mathrm{mM} \mathrm{NaCl}$ and then removed at flowering (Set III), shoot and root dry mass increased modestly up to $\mathrm{d} 75$, but then plants had a remarkable recovery in shoot (Fig. 2a) and root (Fig. 2b) growth by the final sampling. Following removal of the $\mathrm{NaCl}$, plants previously in $20 \mathrm{mM}$ and $40 \mathrm{mM} \mathrm{NaCl}$ up to the reproductive stage had both fully recovered shoot and root dry mass by the final sampling (data not shown).

\subsubsection{Flower and pod numbers}

The numbers of flowers (including buds) and pods were counted every $10 \mathrm{~d}$, during the final $50 \mathrm{~d}$ of the experiment. For plants in continuous $\mathrm{NaCl}$ treatments (Set I), the number of flowers was not affected by $20 \mathrm{mM}$, but at $40 \mathrm{mM}$ had decreased to $40 \%$ and at $60 \mathrm{mM}$ to $4 \%$ of controls (Fig. 3a). Although flower numbers at $20 \mathrm{mM} \mathrm{NaCl}$ did not differ from the control, pod number had declined to $33 \%$ of the control. At $40 \mathrm{mM} \mathrm{NaCl}$, most flowers dropped off so that very few pods were formed, and at $60 \mathrm{mM} \mathrm{NaCl}$ plants died so that none of the very few flowers formed developed into pods (Fig. $3 a$ and $b$ ).

For plants first exposed to $\mathrm{NaCl}$ at flower bud initiation (Set II), flower number increased by $31 \%$ at $20 \mathrm{mM}$, but declined progressively at each higher $\mathrm{NaCl}$ treatment (Fig. 3a). In contrast to the stimulation of flowering by $20 \mathrm{mM} \mathrm{NaCl}$, pod number was less than in the controls (Fig. 3b). Flower and pod numbers were both reduced progressively as $\mathrm{NaCl}$ was increased to 40 and then $60 \mathrm{mM}$ (Fig. 3b). The reductions in pod numbers in plants first exposed to $\mathrm{NaCl}$ at flower bud initiation were, however, much less than those for plants continuously in $\mathrm{NaCl}$ from the early vegetative stage (Fig. 3b). Plants exposed to $\mathrm{NaCl}$ in the vegetative stage and then without $\mathrm{NaCl}$ during the reproductive phase (Set III), all recovered such that flower numbers were equal to those in the control (Fig. 3a). Pod numbers, however, were still reduced in these plants at the final sampling, although this was not a direct on-going effect of the previous $\mathrm{NaCl}$ exposure as many of the flowers formed later in the experiment did not have time to develop into pods before the end of the experiment.

\subsubsection{Ion concentrations in shoots and roots}

Concentrations of $\mathrm{Na}$ (Fig. 4c and d) and $\mathrm{Cl}$ (Fig. 4e and f) remained low in shoots and roots of control plants during the reproductive phase. Plants that continued in the $60 \mathrm{mM} \mathrm{NaCl}$ treatments already contained high tissue concentrations of $\mathrm{Na}$ and $\mathrm{Cl}$, and these only had modest increases prior to death. Plants that remained in $40 \mathrm{mM} \mathrm{NaCl}$, increased in $\mathrm{Na}$ and $\mathrm{Cl}$ concentrations during the reproductive phase and the values reached as much as 15- and 29times those in controls, respectively (Fig. 4c-f). These plants died after $75 \mathrm{~d}$ of $\mathrm{NaCl}$ treatment. Plants that continued in $20 \mathrm{mM} \mathrm{NaCl}$ 


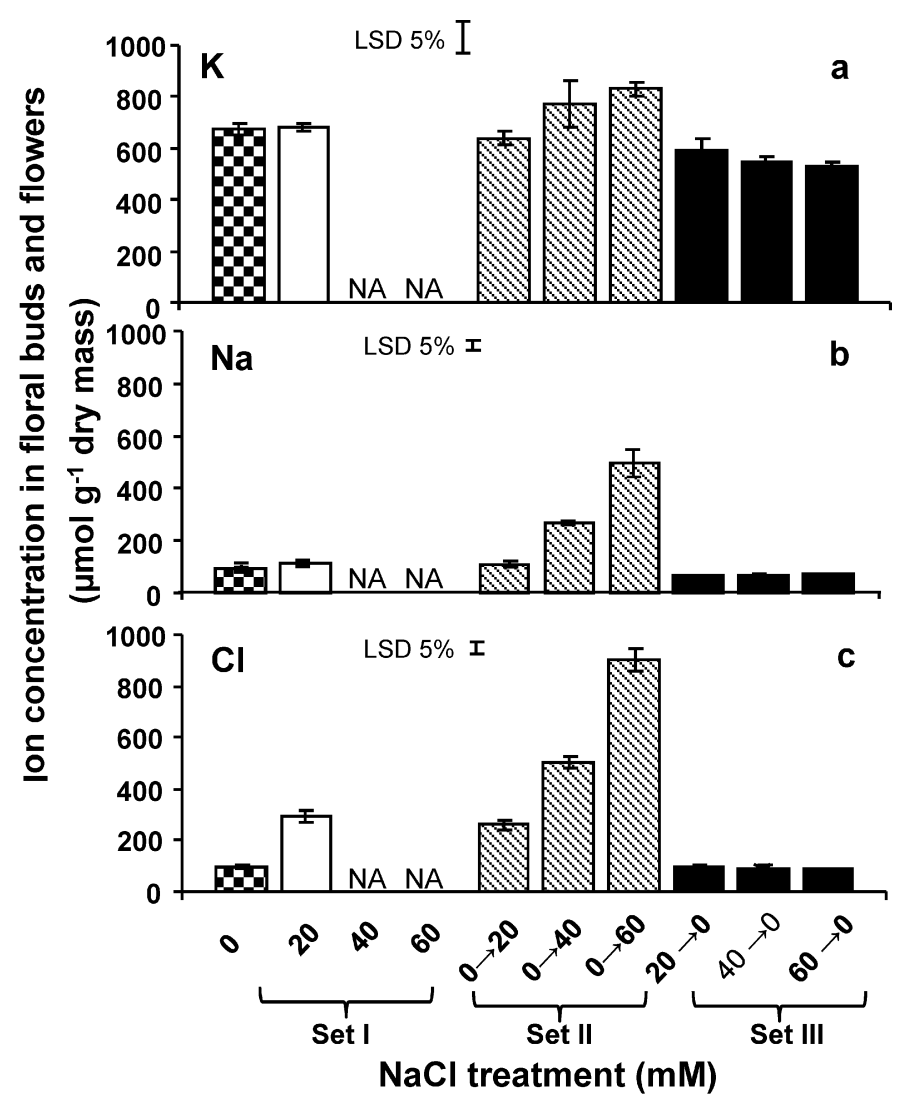

Fig. 5. $\mathrm{K}, \mathrm{Na}$ and $\mathrm{Cl}$ concentrations (a, b and c, respectively) in buds and flowers of chickpea exposed to different concentrations and timing of $\mathrm{NaCl}$ treatments. These floral structures were sampled at the final sampling ( $98 \mathrm{~d}$ of treatments). Set I-continuous $\mathrm{NaCl}$ treatments; Set $\mathrm{II}-\mathrm{NaCl}$ applied at flower bud initiation stage; Set III-NaCl removed at flower bud initiation stage. Data not available (NA) for continuous $40 \mathrm{mM}$ and $60 \mathrm{mM}$ treatments, as plants died before the final sampling. Values given are means \pm SE of 7 replicates. LSD at $P=0.05$ is shown.

also had $\mathrm{Na}$ and $\mathrm{Cl}$ concentrations higher than controls; $\mathrm{Na}$ and $\mathrm{Cl}$ were, respectively, 3.4- and 12-times higher in shoots and 5.4and 13.5-times higher in roots (Fig. 4). In continuous $\mathrm{NaCl}$ treatments (Set I), K concentration did not change in shoots or roots, even though plants soon died in the two highest $\mathrm{NaCl}$ concentrations. By contrast, K concentration decreased significantly (38\%) in roots of plants grown in $20 \mathrm{mM} \mathrm{NaCl}$ (Fig. $4 \mathrm{a}$ and b).

For plants first exposed to $\mathrm{NaCl}$ treatments at the reproductive stage (Set II), shoot Na (Fig. 2c) and Cl (Fig. 2e) increased by the next sampling time (18d) to levels approximately equal to those in plants continuously in the same $\mathrm{NaCl}$ concentrations. Similarly, root $\mathrm{Na}$ (Fig. 2d) and $\mathrm{Cl}$ (Fig. 2f) increased to $80 \%$ of the concentrations in plants continuously exposed to $\mathrm{NaCl}$. Like the vegetative stage (Fig. 1), after the initial increase in tissue $\mathrm{Na}$ and $\mathrm{Cl}$ upon first exposure at flower bud initiation, concentrations in roots remained relatively constant; but in shoots, $\mathrm{Na}$ and $\mathrm{Cl}$ declined modestly by the final sampling. K concentration did not change significantly in shoots or roots of plants with $\mathrm{NaCl}$ treatments imposed at flower bud initiation (Set II) (Fig. 4a and b). General observations across all treatments, for plants near a new steady state in $\mathrm{NaCl}$ treatments (Set I and II), were that Na concentrations were similar in shoots and roots (Fig. 2c and d), whereas $\mathrm{Cl}$ concentrations in shoots were higher than in roots (Fig. 2e and f). Thus, shoot $\mathrm{Cl}$ always exceeded shoot Na, in the vegetative (Fig. 1) and reproductive phase (Fig. 2).

Plants initially in $60 \mathrm{mM} \mathrm{NaCl}$, but removed at flowering (Set III), had large reductions in $\mathrm{Na}$ and $\mathrm{Cl}$ in shoots (Fig. 2a and e) and roots (Fig. $2 \mathrm{~d}$ and f). The reductions were greatest in the first $18 \mathrm{~d}$, but then continued such that, by the end of the experiment, tissue $\mathrm{Na}$

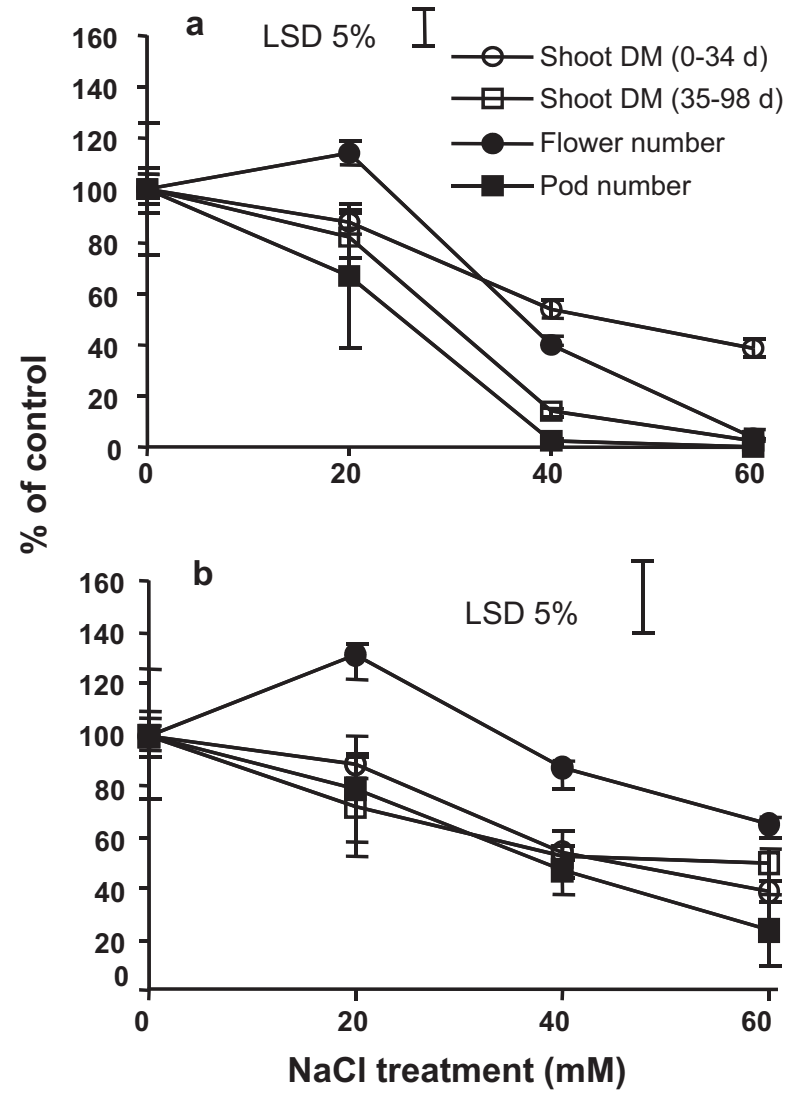

Fig. 6. Responses of chickpea to increasing $\mathrm{NaCl}$ concentrations applied during the (a) vegetative (Set I) and (b) reproductive (Set II) stages. Responses (as \% of control) are shown for vegetative growth (shoot dry mass) and reproductive components (flower and pod numbers). In continuous $40 \mathrm{mM}$ and $60 \mathrm{mM} \mathrm{NaCl}$ (Set I) plants died prior to maturity; only a few flowers, but no pods were formed at $60 \mathrm{mM} \mathrm{NaCl}$. Values given are means \pm SE of 7 replicates. LSD at $P=0.05$ is shown.

and $\mathrm{Cl}$ concentrations did not differ from controls. After removing $\mathrm{NaCl}$ at flowering, shoot $\mathrm{K}$ did not differ at the final sampling irrespective of the previous presence or absence of $\mathrm{NaCl}$ (Fig. 4a). By contrast, in roots the $\mathrm{K}$ concentration did differ at the final sampling; being 28\% higher in plants previously at $60 \mathrm{mM} \mathrm{NaCl}$, but not different to the control when previously at $40 \mathrm{mM} \mathrm{NaCl}$, and $34 \%$ lower than in the control for plants previously at $20 \mathrm{mM} \mathrm{NaCl}$ (Fig. 4b).

\subsubsection{Ion concentrations in floral buds/flowers}

In the continuous $\mathrm{NaCl}$ treatments, plants died in the 40 and $60 \mathrm{mM}$ treatments prior to the final sampling at which floral structures were collected, so floral buds and flowers could only be sampled for the $20 \mathrm{mM}$ treatment and control (Set I). Floral buds and flowers did not show significant differences in tissue $\mathrm{Na}$ concentration between controls and the $20 \mathrm{mM} \mathrm{NaCl}$ treatment (Fig. 5b). Tissue $\mathrm{Cl}$, however, increased 3-fold in these floral tissues of plants at $20 \mathrm{mM} \mathrm{NaCl}$ (Fig. 5c). For plants first exposed to $\mathrm{NaCl}$ at flowering (Set II), Na in floral tissues increased progressively at each higher $\mathrm{NaCl}$ treatment (Fig. 5b), as did $\mathrm{Cl}$ (Fig. 5c). $\mathrm{Cl}$ in floral tissues was equal to that of $\mathrm{Na}$ in controls, but was 2.6, 1.9 and 1.8 times higher than $\mathrm{Na}$ in plants at 20,40 and $60 \mathrm{mM} \mathrm{NaCl}$, respectively (Fig. $5 \mathrm{~b}$ and c). For plants with $\mathrm{NaCl}$ treatments removed at flower bud initiation (Set III), $\mathrm{Na}$ and $\mathrm{Cl}$ concentrations in floral tissues were low by the final sampling, being equivalent to those in controls (Fig. 5b and c). K concentrations in floral buds and flowers (Fig. 5a) were affected much less than those of $\mathrm{Cl}$ (Fig. 5c); no effect was seen for plants continuously in $20 \mathrm{mM} \mathrm{NaCl}$ (Set I). Interestingly, $\mathrm{K}$ increased slightly with higher $\mathrm{NaCl}$ treatments applied at 
flowering (Set II), whereas $\mathrm{K}$ declined to $88-78 \%$ of control values in floral buds/flowers of plants exposed to $\mathrm{NaCl}$ during the vegetative phase and without $\mathrm{NaCl}$ in the reproductive phase (Set III).

\subsubsection{Pollen viability}

Pollen grain germination in vitro was determined to assess viability, as reduced pollen viability was one possible cause of reduced conversion of flowers to pods. Pollen collected from $\mathrm{NaCl}$ treated plants (Set I after 35-40 d of treatments) showed in vitro germination of $99 \%$ ( $20 \mathrm{mM}), 96 \%$ ( $40 \mathrm{mM})$, and $91 \%$ (60 mM). The influence of $\mathrm{NaCl}$ added to the in vitro test solution was also determined for pollen taken from control plants; germination was inhibited by addition of $\mathrm{NaCl}$, being only $30 \%(40 \mathrm{mM}), 27 \%(80 \mathrm{mM})$, and $19 \%$ $(120 \mathrm{mM})$ of control values.

\section{Discussion}

Imposition of $\mathrm{NaCl}$ treatments at flower bud initiation enabled evaluation of the sensitivity of the reproductive phase of chickpea without carry-over effects of prior exposure during the vegetative phase. Such carry-over effects would be large in chickpea exposed to 40 and $60 \mathrm{mM} \mathrm{NaCl}$, owing to high tissue concentrations of $\mathrm{Na}$ and $\mathrm{Cl}$, severe symptoms of shoot damage, and reduced biomass before flowering commenced (see Section 3). Plants exposed to $40 \mathrm{mM} \mathrm{NaCl}$ from the seedling stage produced $2 \%$ of the pods compared with the control, and those at $60 \mathrm{mM}$ did not pod (Fig. 6a). For plants first exposed to $\mathrm{NaCl}$ at flower bud initiation, flower production was affected less by salinity than vegetative growth, but pod formation was more sensitive than vegetative growth (Fig. 6b). Although flower production was inhibited by $\mathrm{NaCl}$ at $40 \mathrm{mM}$ and above, at $20 \mathrm{mM} \mathrm{NaCl}$ flower numbers increased by $14 \%$ in continuous treatments applied to seedlings, and by $31 \%$ when $\mathrm{NaCl}$ was applied at flower bud initiation, compared with the controls (Fig. 6). Similarly, salinity (Na:Ca:Mg 4:1:3 and $\mathrm{Cl}: \mathrm{SO}_{4}$ 7:3) at $20 \mathrm{meq} \mathrm{L}^{-1}$ increased flower numbers 2-fold in earlier studies (Dhingra and Varghese, 1993; Dhingra et al., 1996). In summary, our approach enabled us to test the hypothesis that in chickpea the reproductive phase is more salt-sensitive than vegetative growth, and further strengthened the idea of Vadez et al. (2007) that conversion of flowers to pods appears to be a salt sensitive process. Therefore, screening of chickpea for tolerance at this stage between flowering and seed development under salinity should be a priority for future work.

Sensitivity of flower conversion into pods under saline conditions might be related to high concentrations of $\mathrm{Na}$ and $\mathrm{Cl}$ in floral tissues (Fig. 4). For plants exposed to $60 \mathrm{mM} \mathrm{NaCl}$ starting at flower initiation, Na on a tissue water basis in flowers reached $151 \mathrm{mM}$ $\left(498 \mu \mathrm{molg}^{-1}\right.$ dry mass) and $\mathrm{Cl}$ was $274 \mathrm{mM}\left(903 \mu \mathrm{molg}^{-1}\right.$ dry mass); these are considered to be relatively high concentrations for plant tissues (cf. Munns and Tester, 2008). Interestingly, Na on tissue water basis in flowers $(151 \mathrm{mM})$ did not differ to that in the whole shoot, whereas flower $\mathrm{Cl}$ concentration $(274 \mathrm{mM})$ although still higher than $\mathrm{Na}$, was just under half of the $\mathrm{Cl}$ concentration in the whole shoot $(637 \mathrm{mM}$ ) (calculated from Fig. 4 and 5 and data on tissue water contents). This situation of high Na concentrations in reproductive tissues of chickpea is similar to the situation in rice (Khatun et al., 1995); rice is also very sensitive to salinity during the reproductive phase (Heenan et al., 1988; Khatun et al., 1995). Like chickpea (present study), Na concentrations in floral parts of rice were also similar to, or even exceeded, those in leaves (Khatun et al., 1995). In rice, high Na concentrations even occur in the stigma and pollen (Khatun et al., 1995), so it is also possible that in chickpea high $\mathrm{Na}$ (and possibly $\mathrm{Cl}$ ) concentrations might also occur in these floral parts, in addition to the likely accumulation in the transpiring outer parts of flowers. Future research should elucidate the delivery pathways of $\mathrm{Na}$ and $\mathrm{Cl}$ into floral tissues of salt-sensitive species such as chickpea and rice.

It seems likely that accumulation of $\mathrm{Na}$ and/or $\mathrm{Cl}$ to toxic levels in floral tissues might compromise flower to pod conversion in chickpea in saline conditions, as high tissue ions can cause toxicities and/or disturb tissue water relations (cf. Munns and Tester, 2008). Pollen from salt-treated chickpea (even at $60 \mathrm{mM} \mathrm{NaCl}$ ) was viable, giving $91 \%$ germination in vitro, but pollen germination in vitro was severely inhibited by addition of $40 \mathrm{mM} \mathrm{NaCl}$ to the germination medium. Similar to chickpea, salinized tomato retained pollen viability (Grumberg et al., 1995) and pollen germination was inhibited in vitro by $\mathrm{NaCl}$ of $34 \mathrm{mM}$ and above (Foolad, 2004). In rice, both pollen viability and stigma receptivity were reduced in saline conditions, and by most in genotypes with the highest $\mathrm{Na}$ concentrations in these floral parts (Khatun et al., 1995). Moreover, in chickpea experiencing water deficits, stigma receptivity declines markedly (Fang et al., 2010). So, if $\mathrm{Na}$ and $\mathrm{Cl}$ had accumulated in the stigma of salinized chickpea, then it seems reasonable to expect that in vivo pollen germination and pollen tube growth would have been inhibited, thereby reducing conversion of flowers to pods and thus seed numbers. Although not evaluated in the present study, seed size in chickpea can also be reduced under saline conditions (e.g. by $20 \%$, Vadez et al., 2007), and entry of $\mathrm{Na}$ and $\mathrm{Cl}$ into seeds (Murumkar and Chavan, 1986; Mamo et al., 1996) might have contributed to these declines if these ions adversely affected metabolism, in addition to possible declines in photosynthate available for seed-filling in salinized plants (cf. suggested for rice, Khatun et al., 1995).

$\mathrm{Na}$ and $\mathrm{Cl}$ concentrations in vegetative (present study and see also Lauter and Munns, 1987) and reproductive phases (present study) reached relatively steady levels after 10 and $18 \mathrm{~d}$ of treatment, respectively; after which, more or less the same tissue concentrations were maintained. The growth reduction and leaf damage could have resulted from an interaction of time with the concentration of $\mathrm{Na}$ and/or $\mathrm{Cl}$ in the tissue (cf. Wilson et al., 1970; Munns et al., 1995). With time some leaves died; leaf death was most likely caused by ion toxicity, although it is difficult to separate individual effects of $\mathrm{Na}$ and $\mathrm{Cl}$ (cf. Munns and Tester, 2008). When the capacity of cells to store ions is exceeded, ion toxicity occurs in the cytoplasm and/or ions build up in intercellular spaces, leading to cell dehydration and death (Munns, 1993), and although $\mathrm{Na}$ is most commonly regarded as the toxic ion in many species suffering salt damage, $\mathrm{Cl}$ toxicity occurs in several saltsensitive species (Munns and Tester, 2008). For chickpea, Lauter et al. (1981) and Dua (1998) considered the predominance of $\mathrm{Cl}$ in salt injury, whereas in other work based on studies using $\mathrm{NaCl}(50 \mathrm{mM})$ and $\mathrm{Na}_{2} \mathrm{SO}_{4}(25 \mathrm{mM}) \mathrm{Na}$ damage was considered to be more than that of $\mathrm{Cl}$ (Lauter and Munns, 1986, 1987). In chickpea shoots, critical Na concentrations have been reported as 200-270 $\mu \mathrm{molg}^{-1}$ dry mass (Lauter and Munns, 1987) and critical $\mathrm{Cl}$ concentrations at $\sim 450 \mu \mathrm{molg}^{-1}$ dry mass (Reuter and Robinson, 1986). In the present experiment, plants at $20 \mathrm{mM} \mathrm{NaCl}$, that suffered growth reductions of $17 \%$, had shoot $\mathrm{Na}$ and $\mathrm{Cl}$ concentrations of 115 and $500 \mu \mathrm{mol} \mathrm{g}^{-1}$ dry mass, respectively; as $\mathrm{Cl}$ exceeded the critical concentration, whereas $\mathrm{Na}$ did not, $\mathrm{Cl}$ might have predominately caused the toxicity. At higher external $\mathrm{NaCl}(60 \mathrm{mM})$ shoots also contained 2.25 (vegetative phase) and 2.65 (reproductive phase) higher $\mathrm{Cl}$ than $\mathrm{Na}$; being consistent with other studies of chickpea reporting that shoot concentrations of $\mathrm{Cl}$ exceed those of $\mathrm{Na}$ (e.g. Mamo et al., 1996). Further, shoot Na concentration was lower than in roots in all treatments whereas the opposite occurred for $\mathrm{Cl}$, i.e., shoot $\mathrm{Cl}$ exceeded root concentrations (Fig. 4). Thus, the present data indicate $\mathrm{Cl}$ toxicity in shoots as a likely contributing mechanism causing salt sensitivity in chickpea. 
Chickpea exposed to $60 \mathrm{mM} \mathrm{NaCl}$ died after $52 \mathrm{~d}$, whereas those transferred back to non-saline solutions at flower initiation (after $34 \mathrm{~d}$ at $60 \mathrm{mM} \mathrm{NaCl}$ ) recovered (Fig. 2). These plants had $60 \%$ less shoot dry mass when transferred back to nonsaline conditions, but recovered by producing new branches and, although later, the same numbers of flowers as the non-saline control. This response of chickpea contrasts with that of cowpea (also with indeterminate growth); for cowpea, when salinity was removed after $20 \mathrm{~d}$ of salinization in the vegetative phase, vegetative shoot growth and seed yields were still significantly reduced compared with when salinity was applied at flowering and pod filling stages (Maas and Poss, 1989). In the present study, ion concentrations in shoots and roots declined during recovery, back to control levels. Ions present when transferred to non-saline conditions would have been diluted by new growth, lost in old leaves that dropped, and some efflux from the roots could also have occurred. The capacity to recover after saline levels decrease might be an important adaptation in field situations with fluctuating salinity levels, such as in southern Australia (Rengasamy, 2006) and presumably other Mediterranean cropping environments.

\subsection{Conclusions}

$\mathrm{NaCl}$ at $40 \mathrm{mM}$ (or above) applied to chickpea seedlings or to plants at flower initiation stage, in both cases reduced root and shoot growth and flower and pod numbers, eventually causing death when 40 or $60 \mathrm{mM}$ was applied at the seedling stage and continued. Both vegetative and reproductive stages of chickpea were sensitive to continuous $\mathrm{NaCl}$ exposure; but conversion of flowers to pods appears to be particularly salt sensitive. Sensitivity occurred even for a reputably 'tolerant' cultivar (JG 11; Vadez et al., 2007) at $\mathrm{NaCl}$ levels (viz. 20 and $40 \mathrm{mM}$ ) that would be considered as relatively mild for many crops (e.g. wheat, Colmer et al., 2005) with which chickpea might be grown in rotation. Upon removal of $\mathrm{NaCl}$, however, chickpea showed excellent recovery with substantial new shoot growth, presumably aided by an indeterminate growth habit. Sensitivity during the reproductive stage was not caused by changes in pollen viability but was potentially due to toxic accumulation of $\mathrm{Na}$ and $\mathrm{Cl}$ in flowers, and possibly the sensitivity of pollen tube growth if $\mathrm{NaCl}$ entered the stigma. Evaluations of salt tolerance in chickpea need to include reproductive, as well as earlier growth stages.

\section{Acknowledgements}

We thank Neil Turner (CLIMA, UWA) and Vincent Vadez (ICRISAT) for comments on a draft of this manuscript. Australian Department of Education, Employment and Workplace Relations (DEEWR) for supporting S.S. with a PhD scholarship through the Endeavour Postgraduate Award. We thank the Australian Research Council (ARC) and Council of Grain Growers Association (COGGO) for operating funds for this research via ARC Linkage Project LP0776586.

\section{References}

Alexander, M.P., Ganeshan, S., 1989. An improved cellophane method for in vitro germination of recalcitrant pollen. Stain Technol. 64, 225-227.

Ali, M.Y., Krishnamurthy, L., Saxena, N.P., Rupela, O.P., Kumar, J., Johansen, C., 2002. Scope for genetic manipulation of mineral acquisition in chickpea. Plant Soil 245, 123-134.

Al-Mutata, M., 2003. Effect of salinity on germination and seedling growth of chickpea (Cicer arietinum) genotypes. Int. J. Agric. Biol. 5, 226-229.

Ashraf, M., Waheed, A., 1993. Response of some genetically lines of chickpea (Cicer arietinum L.) to salt. Plant Soil 154, 257-266.

Baalbaki, R.Z., Zurayk, R.A., Adlan, M.A.M., Saxena, M.C., 2000. Effect of nitrogen source and salinity level on salt accumulation of two chickpea genotypes. J. Plant Nutr. 23, 805-814.
Brewbaker, J.L., Kwack, B.H., 1963. The essential role of calcium ion in pollen germination and pollen tube growth. Am. J. Bot. 50, 747-858.

Bruggeman, A., Hamdy, A., Touchan, H., Karajeh, F., Oweis, T., 2003. http://ressources.ciheam.org/om/pdf/b44/03001803.pdf.

Colmer, T.D., Munns, R., Flowers, T.J., 2005. Improving salt tolerance of wheat and barley: future prospects. Aust. J. Exp. Agric. 45, 1425-1443.

Dhingra, H.R., Varghese, T.M., 1993. Flowering and male reproductive functions of chickpea (Cicer arietinum L) genotypes as affected by salinity. Biol. Plantarum 35, 447-452.

Dhingra, H.R., Kajal, N., Chhabra, S., Varghese, T.M., 1996. Flowering pattern and yield correlation in gram (Cicer arietinum) under influence of salinity and growthregulators. Indian J. Agr. Sci. 66, 230-233.

Dua, R.P., 1998. Salinity tolerance in chickpea (Cicer arientinum L.). Indian J. Plant Phys. 3, 102-106.

Dua, R.P., Sharma, S.K., 1997. Suitable genotypes of gram (Cicer arietinum) and mechanism of their tolerance to salinity. Indian J. Agr. Sci. 67, 440-443.

Elsheikh, E.A.E., Wood, M., 1990. Effect of salinity on growth, nodulation and nitrogen yield of chickpea (Cicer arietinum L.). J. Exp. Bot. 41, 1263-1269.

Fang, X., Turner, N.C., Yan, G., Li, F., Siddique, K.H.M., 2010. Flower numbers, pod production, pollen viability, and pistil function are reduced and flower and pod abortion increased in chickpea (Cicer arietinum L.) under terminal drought. J. Exp. Bot. 61, 335-345

Flowers, T.J., Gaur, P.M., Gowda, C.L.L., Krishnamurthy, L., Samineni, S., Siddique, K.H.M., Turner, N.C., Vadez, V., Varshney, R.K., Colmer, T.D., 2010. Salt sensitivity in chickpea. Plant Cell Environ. 33, 490-509.

Foolad, M.R., 2004. Recent advances in genetics of salt tolerance in tomato. Plant Cell Tissue Organ Cult. 76, 101-119.

Garg, B.K., Gupta, I.C., 1998. Physiology of salt tolerance of arid zone crops. V. Chickpea. Curr. Agr. 22, 21-37.

Ghassemi, F., Jackman, A.J., Nix, H.A., 1995. Salinization of Land and Water Resources: Human Causes, Extent Management and Case Studies. UNSW Press/CAB International, Sydney, Australia/Wallingford, UK.

Grumberg, K., Fernandaze-Munoz, R., Cuartero, J., 1995. Growth, flowering and quality of pollen of tomato plants grown under saline conditions. Acta Hortic. 412, 484-489.

Heenan, D.P., Lewin, L.G., McCaffery, D.W., 1988. Salinity tolerance in rice varieties at different growth stages. Aust. J. Exp. Agr. 28, 343-349.

Karajeh, F., Hamdy, A., Bruggeman, A., Touchan, H., Oweis, T., 2003. In vitro salinity tolerance screening of some legumes and forages cultivars. In: Hamdy, A (Ed.), Regional Action Programme (RAP): Water Resources Management And Water Saving in Irrigated Agriculture (WASIA PROJECT) Bari: CIHEAM-IAMB. , pp. 163-169.

Katerji, N., van Hoorn, J.W., Hamdy, A., Mastrorilli, M., Oweis, T., Malhotra, R.S., 2001. Response to soil salinity of two chickpea varieties differing in drought tolerance. Agr. Water Manag. 50, 83-96.

Katerji, N., van Hoorn, J.W., Hamdy, A., Mastrorilli, M., Oweis, T., 2005. Salt tolerance analysis of chickpea, faba bean and durum wheat varieties. I. Chickpea and faba bean. Agr. Water Manag. 72, 177-194.

Keating, B.A., Fisher, M.J., 1985. Comparative tolerance of tropical grain legumes to salinity. Aust. J. Agric. Res. 36, 373-383.

Khalid, M.N., Iqbal, H.F., Tahir, A., Ahmad, A.N., 2001. Germination potential of chickpeas (Cicer arietinum) under saline conditions. Pak. J. Biol. Sci. 4, 395-396.

Khatun, S., Rizzo, C.A., Flowers, T.J., 1995. Genotypic variation in the effect of salinity on fertility in rice. Plant Soil 173, 239-325.

Lauter, D.J., Munns, D.N., Clarkin, K.L., 1981. Salt response of chickpea as influenced by N supply. Agron. J. 73, 961-966.

Lauter, D.J., Munns, D.N., 1986. Salt resistance of chickpea genotypes salinized with $\mathrm{NaCl}$ or $\mathrm{Na}_{2} \mathrm{SO}_{4}$. Plant Soil 95, 271-279.

Lauter, D.J., Munns, D.N., 1987. Salt sensitivity of chickpea during vegetative growth and at different humidities. Aust. J. Plant Physiol. 14, 171-180.

Maas, E.V., Poss, J.A., 1989. Salt sensitivity of cowpea at various growth stages. Irrigation Sci. 10, 313-320.

Maliro, M.F.A., McNeil, D., Redden, B., Kollmorgen, J.F., Pittock, C., 2008. Sampling strategies and screening of chickpea (Cicer arietinum L.) germplasm for salt tolerance. Genet. Resour. Crop Evol. 55, 53-63.

Mamo, T., Richter, C., Heiligtag, B., 1996. Salinity effects on the growth and ion contents of some chickpea (Cicer arietinum $\mathrm{L}$ ) and lentil (Lens culinaris medic) varieties. J. Agron. Crop Sci. 176, 235-247.

Manchanda, H.R., Sharma, S.K., 1989. Tolerance of chloride and sulphate salinity in chickpea (Cicer arietinum). J. Agr. Sci. 113, 407-410.

Munns, R., 1993. Physiological processes limiting plant growth in saline soils: some dogmas and hypotheses. Plant Cell Environ. 16, 15-24.

Munns, R., Schachtman, D.P., Condon, A.G., 1995. The significance of the two-phase growth response to salinity in wheat and barley. Aust. J. Plant Physiol. 13, 757-766.

Munns, R., Tester, M., 2008. Mechanisms of salinity tolerance. Annu. Rev. Plant Biol. 59, 651-681.

Murumkar, C.V., Chavan, P.D., 1986. Influence of salt stress on biochemical processes in chickpea, Cicer arietinum L. Plant Soil 96, 439-443.

Rao, D.L.N., Giller, K.E., Yeo, A.R., Flowers, T.J., 2002. The effects of salinity and sodicity upon nodulation and nitrogen fixation in chickpea (Cicer arietinum). Ann. Bot. 89, 563-570.

Rengasamy, P., 2006. World salinization with emphasis on Australia. J. Exp. Bot. 57, 1017-1023.

Reuter, D.J., Robinson, J.B., 1986. Plant Analysis: An Interpretation Manual. Inkata Press, Melbourne. 
Ryan, J.G., 1997. A global perspective on pigeonpea and chickpea sustainable production systems; present status and future potential. In: Asthana, A.N., Ali, M. (Eds.), Recent Advances in Pulses Research. Indian Society of Pulses Research and Development, IIPR, Kanpur, India, pp. 1-31.

Sadiki, M., Rabih, K., 2001. Selection of chickpea (Cicer arietinum) for yield and symbiotic nitrogen fixation ability under salt stress. Agronomie 21, 659666.

Sekeroglu, N., Kara, S.M., Dede, O., Askin, T., 1999. Effect of salinity on germination, early seedling growth, Na and K constituents in chickpea. Turk. J. Field Crops 4, $79-84$.

Singh, A.K., 2004. The physiology of salt tolerance in four genotypes of chickpea during germination. J. Agric. Sci. Technol. 6, 87-93.

Sleimi, N., Lachaal, M., Abdelly, C., Soltani, A., Hajji, M., 2001. Physiological behaviour of two chickpea Tunisian varieties irrigated with saline nutrient solution. In: Horst Jea (Ed.), Plant Nutrition-Food Security and Sustainability of Agroecosystems. Kluwer, The Netherlands, pp. 408-409.
Stoddard, F.L., Balko, C., Erskine, W., Khan, H.R., Link, W., Sarker, A., 2006. Screening techniques and sources of resistance to abiotic stresses in cool-season food legumes. Euphytica 147, 167-186.

Vadez, V., Krishnamurthy, L., Serraj, R., Gaur, P.M., Upadhyaya, H.D., Hoisington, D.A. Varshney, R.K., Turner, N.C., Siddique, K.H.M., 2007. Large variation in chickpea is explained by differences in sensitivity at the reproductive stage. Field Crops Res. 104, 123-129.

van Hoorn, J.W., Katerji, N., Hamdy, A., Mastrorilli, M., 2001. Effect of salinity on yield and nitrogen uptake of four grain legumes and on biological nitrogen contribution from the soil. Agric. Water Manag. 51, 87-98.

Wilson, J.R., Haydock, K.P., Robins, M.F., 1970. The development in time of stress effects in two species of Glycine differing in sensitivity to salt. Aust. J. Biol. Sci. 23, 537-551.

Zurayk, R., Adlan, M., Baalbaki, R., Saxena, M.C., 1998. Interactive effects of salinity and biological nitrogen fixation on chickpea (Cicer arietinum L.) growth. J. Agron. Crop Sci. 180, 249-258. 